\title{
Prevalence of low androgen levels among middle and old age men attending Outpatient Clinics
}

\author{
Original \\ Taha Abdelnaser', Dina El Gayar', Islam F. Soliman Abddelrahmana', Ramy \\ Taher $^{3}$ \\ Article \\ ${ }^{1}$ Departments of Andrology, ${ }^{2}$ Clinical and Chemical Pathology, Faculty of Medicine, \\ Cairo University, Cairo \\ ${ }^{3}$ Ministry of Health Hospitals, Egypt, Cairo
}

\begin{abstract}
Introduction: Tiredness is a common symptom of hypogonadism, which can be profound, but there are many medical practitioners who do not include the assessment of testosterone levels in the clinical workup of this symptom. Although male hypogonadism is an established clinical condition, which can be treated, many men experiencing it are undiagnosed.

Aim:The aim was to assess the prevalence of low androgen level among middle and old age men in a cohort of patients attending Kasr Elaini hospital outpatient clinics.

Patients and Methods: A total of 265 male patients older than 40 years attending the outpatient clinics in different specialty were included. All included men were subjected to full history taking and complete general and local examinations. All participants were interviewed personally face to face using Arabic generic version of full aging male scale (AMS) questionnaire. Venous blood samples were withdrawn between 8 and 10 a.m. after a 12-h overnight fast for measurements of total and free testosterone levels.

Results: The mean total testosterone level was $4.0 \pm 2.6 \mathrm{ng} / \mathrm{ml}$, ranging from 0.4 to $16.4 \mathrm{ng} / \mathrm{ml}$. The mean free testosterone level was $6.9 \pm 2.4 \mathrm{pg} / \mathrm{ml}$, with range between 1.4 and $18.5 \mathrm{pg} / \mathrm{ml}$. Low androgen level was founded in $19.2 \%$ of the participants based on total testosterone and in $36.2 \%$ when adding the participants with low free testosterone levels. AMS score showed statistically significant difference between age groups $(P<0.001)$. Age is negatively correlated with total and free testosterone levels ( $\mathrm{r}=-0.226$ and -0.242 , respectively), but the correlation is weak. Total testosterone level shows strong positive correlation with free testosterone level and weak negative correlation with AMS score ( $\mathrm{r}=0.732$ and -0.240 , respectively).

Conclusion: The prevalence of hypogonadism among middle and old age males seeking medical consultation in different specialties may be high.
\end{abstract}

Key Words: Hypogonadism, low androgen, middle and old age, testosterone

Received:7 June 2018, Accepted: 22 June 2018

Corresponding Author: Islam F. S. Abdelrahman, MD, MRCS, FECSM, FEAA, Department of Andrology, Faculty of Medicine, Cairo University, Cairo, Egypt, Zip Code:11553, Tel.:+201004244360, Fax:+202236879, E-mail: islamandrology@yahoo.com

ISSN: 2090-6048, June 2018, Vol. 8, No. 2

\section{INTRODUCTION}

Although male hypogonadism is an established clinical condition, which can be treated, many men experiencing it are undiagnosed. There are several reasons for this, which include a lack of general clinical awareness, the nonspecificity of its symptoms, biochemical tests that are not always easy to interpret, concerns over the safety of testosterone replacement therapy especially in older men, and the false perception that testosterone is a sex hormone that has no other specific health benefits. Tiredness is a common symptom of hypogonadism, which can be profound, but there are many medical practitioners who do not include the assessment of testosterone levels in the clinical workup of this symptom. Hypogonadism impairs well-being and quality of life and puts relationships and employment at risk ${ }^{[1,2]}$.

\section{AIM}

The aim was to assess the prevalence of low androgen level among middle and old age men in a cohort of patients attending Kasr Elaini hospital outpatient clinics.

\section{MATERIALS AND METHODS}

This study was carried out on 265 male patients older than 40 years attending the outpatient clinics in different specialties of Kasr El Aini Hospital, Cairo University, after obtaining the approval from the Andrology Department 
ethical committee. Males younger than 40 years or with history of puberty disorder, patients with hypogonadism on androgen replacement therapy, as well as patients with known history of prostatic cancer who received antiandrogen all were excluded from the study. All included men were subjected to full history taking and complete general and local examinations. All participants were interviewed personally face to face using Arabic generic language to full aging male scale (AMS) questionnaire, which was originally developed in Germany in 1999. The summation of the response points of the participants started from below 26 and higher. The higher the score, the more impairment is present. It is classified into no impairment with score less than 26 , little impairment with score ranging from 27 to 36 , moderate impairment with score ranging from 37 to 49 , and severe impairment with scores more than $50^{[3]}$.

Venous blood samples were withdrawn from all participants between 8 and 10 a.m. after a 12-h overnight fast for measurements of total and free testosterone levels. Total and free testosterone hormone assays were performed in the Chemical Pathology Department at the Cairo University Medical School (Kasr El Aini). Total and free testosterone levels were measured by radio immunoassay kit supplied by DIA source Immunoassays S.A. (Belgium), Ottignies-Louvain-laNeuve, Belgium DIAsource is the company name and read using Cobra II Auto-Gamma counter. Regarding hypogonadism, reference values for total testosterone level was less than or equal to $230 \mathrm{ng} / \mathrm{dl}$ or less than or equal to $2.3 \mathrm{ng} / \mathrm{ml}^{[4]}$. For the free testosterone level, the reference range was obtained from radio immunoassay kit, with reference range of less than or equal to $6.1 \mathrm{pg} / \mathrm{ml}$ in males less than 60 years old and less than or equal to $5 \mathrm{pg} / \mathrm{ml}$ in males more than 60 years old.

\section{RESULTS}

The characteristic data of the included participants in the study, including age, residency, BMI, smoking, erectile dysfunction, and comorbidity, are shown in Table 1.

Hormonal levels among participants, AMS scores, and their classification are represented in Table 2. As shown in Table 2, the mean total testosterone level was $4.0 \pm 2.6 \mathrm{ng} / \mathrm{ml}$, ranging from 0.4 to $16.4 \mathrm{ng} / \mathrm{ml}$.
The mean free testosterone level was $6.9 \pm 2.4 \mathrm{pg} / \mathrm{ml}$, with range between 1.4 and $18.5 \mathrm{pg} / \mathrm{ml}$. Low androgen level was found in $19.2 \%$ of the participants based on the total testosterone level and in $36.2 \%$ when individuals with low free testosterone level were added. AMS score was $35.9 \pm 6.1$ and ranged from 17.0-52.0. Normal participants represented $6.8 \%$, whereas those with low and moderate impairments were comparable at 45.3 and $47.9 \%$, respectively. These results indicated high prevalence of androgen deficiency among middle age and old age patients attending the outpatient clinics.

Linear correlations between different numeric variables of the study are shown in Table 3.

Age is negatively correlated with total and free testosterone levels ( $\mathrm{r}=-0.226$ and -0.242 , respectively), but the correlation is weak. However, it is positively correlated with AMS score $(\mathrm{r}=0.405)$. Total testosterone level shows strong positive correlation with free testosterone and weak negative correlation with AMS score $(\mathrm{r}=0.732$ and -0.240 , respectively).

The participants are grouped according to their age into three groups: group 1 (40-49 years), group 2 (50-59 years), and group 3 ( $\geq 60$ years).

All groups were comparable regarding BMI $(P>0.05)$. AMS score was statistically significant $(P<0.001)$. The younger age has higher percentage of no impairment (15.3\%), as shown in Table 4.

In Table 4, AMS score showed statistically significant difference between age groups $(P<0.001)$. Moderate impairment was lower $(16.9 \%)$ in young age (40-49 years) compared with 51.8 and $62.1 \%$ in age groups $50-59$ and $\geq 60$, respectively; all groups were significantly different from each other.

Comparison between different age groups regarding both total and free testosterone levels showed that there is a statistically significant difference between groups, as both total and free testosterone levels decrease with age (Table 5).

The prevalence of low androgen levels (either low total testosterone or free testosterone or both) in different age groups is presented in Table 6. It showed no statistical significant difference.

Table 1: Characteristics of participants in the study $(n=265)$ 
Rural

Age (years)

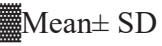

Anthropometric measures

Weight $(\mathrm{kg})$

Height (cm)

WC $(\mathrm{cm})$

BMI $(\mathrm{kg} / \mathrm{m} 2)$

BMI classifications

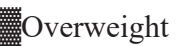

$83(31.3)$

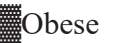

Normal

Smokers

Yes

Smoking type

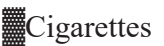

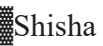

ED

Yes

Comorbidity

\section{糮CVS}

Medical CNS

HTN
$131(49.4)$

$51(19.2)$

$158(59.6)$

$112(70.9)$

$46(29.1)$

$191(72.1)$

$29(10.9)$

$1(0.4)$

$36(13.6)$
$65.3 \pm 8.5^{\mathrm{a}}\left(40-83^{\mathrm{b}}\right)$

$$
\begin{aligned}
& 85.2 \pm 14.9^{\mathrm{a}}\left(50-130^{\mathrm{b}}\right) \\
& 168.4 \pm 7.6^{\mathrm{a}}\left(150-197^{\mathrm{b}}\right) \\
& 98.0 \pm 15.6^{\mathrm{a}}\left(63-192^{\mathrm{b}}\right) \\
& 29.9 \pm 5.3^{\mathrm{a}}\left(19.3-58^{\mathrm{b}}\right)
\end{aligned}
$$

${ }^{\text {aD }}$ ata presented as mean \pm SD.

${ }^{\text {bRange of data. }}$

CVS, cardiovascular diseases; DM, diabetes mellitus; ED, erectile dysfunction; HTN, hypertension; WC, waist circumference. 
Table 2: Hormonal score levels and their classification in the studied participants $(\mathrm{n}=265)$

\begin{tabular}{|c|c|c|}
\hline & Mean \pm SD & Minimum-maximum \\
\hline Total testosterone & $4.0 \pm 2.6 \mathrm{ng} / \mathrm{ml}$ & $0.4-16.4$ \\
\hline Free testosterone & $6.9 \pm 2.4 \mathrm{pg} / \mathrm{ml}$ & $1.4-18.5$ \\
\hline AMS score & $35.9 \pm 6.1$ & $17-52$ \\
\hline \multicolumn{3}{|l|}{ AMS score $[\mathrm{n}(\%)]$} \\
\hline 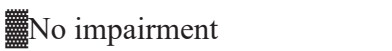 & $18(6.8)$ & \\
\hline Little & $120(45.3)$ & \\
\hline Moderate & $127(47.9)$ & \\
\hline Low free testosterone $[\mathrm{n}(\%)]$ & $96(36.2)$ & \\
\hline Low total testosterone $[\mathrm{n}(\%)]$ & $51(19.2)$ & \\
\hline
\end{tabular}

AMS, aging male scale.

Table 3: Correlation between different study variables $(n=265)$

\begin{tabular}{|c|c|c|c|}
\hline & $\mathrm{R}$ & & Pvalue \\
\hline \multicolumn{4}{|l|}{ Age } \\
\hline BI & -0.012 & 0.844 & NS \\
\hline Total testosterone & -0.226 & $<0.001$ & Weak negative \\
\hline 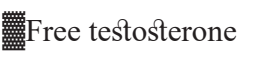 & -0.242 & $<0.001$ & Weak negative \\
\hline 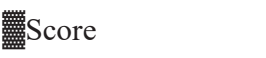 & 0.405 & $<0.001$ & Weak positive \\
\hline \multicolumn{4}{|l|}{ BMI } \\
\hline 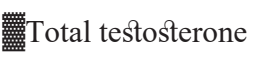 & -0.014 & 0.827 & NS \\
\hline 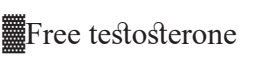 & -0.084 & 0.174 & NS \\
\hline Score & -0.045 & 0.469 & NS \\
\hline \multicolumn{4}{|l|}{ Total testosterone } \\
\hline Wree testosterone & 0.732 & $<0.001$ & Strong positive \\
\hline Score & -0.240 & $<0.001$ & Weak negative \\
\hline \multicolumn{4}{|l|}{ Free testosterone } \\
\hline Score & -0.210 & 0.001 & Weak negative \\
\hline
\end{tabular}

$P \leq 0.05$ is significant.

$r$, correlation coefficient. 
Table 4: BMI categories, aging male scale score, and low free androgen in relation to different age groups $(\mathrm{n}=265)$

\begin{tabular}{|c|c|c|c|c|}
\hline \multicolumn{5}{|c|}{ Age groups [n (\%)] } \\
\hline & $40-49(n=59)$ & $50-59(\mathrm{n}=110)$ & $\geq 60(n=96)$ & Pvalue \\
\hline \multicolumn{5}{|l|}{ BMI } \\
\hline 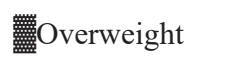 & $20(33.9)$ & $31(28.2)$ & $32(33.3)$ & 0.907 \\
\hline 粃Obese & $29(49.2)$ & $56(50.9)$ & $46(47.9)$ & \\
\hline Normal & $10(16.9)$ & $23(20.9)$ & $18(18.8)$ & \\
\hline \multicolumn{5}{|l|}{ AMS Score ${ }^{\mathrm{a}}$} \\
\hline No impairment & $9(15.3)$ & $4(3.6)$ & $5(5.3)$ & $<0.001$ \\
\hline 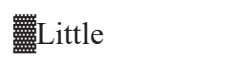 & $40(67.8)$ & $49(44.5)$ & $31(32.6)$ & \\
\hline Moderate & $10(16.9)$ & $57(51.8)$ & $59(62.1)$ & \\
\hline
\end{tabular}

$P \leq 0.05$ is significant.

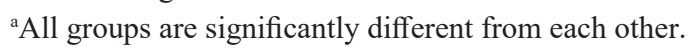

Table 5: Total testosterone and free testosterone levels $($ mean \pm SD) in relation to different age groups $(n=265)$

\begin{tabular}{|c|c|c|c|c|c|c|c|}
\hline \multicolumn{8}{|c|}{ Age groups } \\
\hline & \multicolumn{2}{|c|}{$40-49(\mathrm{n}=59)$} & \multicolumn{2}{|c|}{$50-59(\mathrm{n}=110)$} & \multicolumn{2}{|c|}{$\geq 60(n=96)$} & \\
\hline & Mean & $\mathrm{SD}$ & Mean & SD & Mean & SD & Pvalue \\
\hline $\begin{array}{l}\text { Total } \\
\text { testosterone }\end{array}$ & 4.8 & $2.1^{\mathrm{a}}$ & 5.2 & $2.9^{\mathrm{b}}$ & 3.6 & $2.2^{\mathrm{a}-\mathrm{b}}$ & $<0.001$ \\
\hline $\begin{array}{l}\text { Free } \\
\text { testosterone }\end{array}$ & 7.6 & $2.1^{\mathrm{a}}$ & 7.4 & $2.6^{\mathrm{b}}$ & 6.1 & $2.2^{\mathrm{a}-\mathrm{b}}$ & $<0.001$ \\
\hline
\end{tabular}

$P \leq 0.05$ is significant, similar letters indicate statistical significant difference.

*All groups are significantly different from each other.

Table 6: Comparison between different age groups according to prevalence of low androgen levels

\begin{tabular}{|c|c|c|c|c|}
\hline \multicolumn{5}{|l|}{ Age groups } \\
\hline & $40-49(\mathrm{n}=59)$ & $50-59(\mathrm{n}=110)$ & $\geq 60(\mathrm{n}=96)$ & $P$ value \\
\hline Low androgen & $19 / 59(32.2 \%)$ & $47 / 110(42.7 \%)$ & $37 / 96(38.5 \%)$ & 0.407 \\
\hline
\end{tabular}




\section{DISCUSSION}

Many studies have aimed to investigate the prevalence of androgen deficiency in different populations based on total testosterone level $(2.1-38.7 \%)$ and free testosterone $(36.2-40 \%)^{[5-10]}$. In the current study, the prevalence of low androgen level was $19.2 \%$ based on total testosterone level and in $36.2 \%$ when adding the participants with low free testosterone levels. These percentages were comparable to studies done by Araujo et $a l .{ }^{[6]}$, which showed a prevalence of $25.3 \%$ in the same age group of greater than or equal to 40 -year-old participants with TT cut-off value of $400 \mathrm{ng} / \mathrm{dl}$ and FT of less than $8.9 \mathrm{ng} / \mathrm{dl}$. In addition, our results were comparable to another study done by Araujo et al. ${ }^{[7]}$, as they showed that $24 \%$ of the participants have TT less than or equal to $300 \mathrm{ng} / \mathrm{dl}$ in males aged $30-70$ years old. Moreover, $\sim 11 \%$ have FT of less than or equal to 0.17 nmol/1, and 9.3\% have low levels of TT and FT. Another study was carried on 734 participants in Taiwan. It showed that $24.1 \%$ of participants showed TT level of less than $300 \mathrm{ng} / \mathrm{dl}$, and $16.6 \%$ showed lower both TT and FT $(\mathrm{TT}<300 \mathrm{ng} / \mathrm{dl} \text { and } \mathrm{FT}<5 \mathrm{ng} / \mathrm{dl})^{[10]}$. However, Mulligan et al. $^{[5]}$, in 2006, studied the prevalence of hypogonadism among 2650 participants. The study showed that $38.7 \%$ of participants had low TT level $(<300 \mathrm{ng} / \mathrm{dl})$, which increased to $40 \%$ when FT level was used $(<52 \mathrm{ng} / \mathrm{dl})$. These results are much higher than in the current study. However, this can be explained by that in Mulligan et al. ${ }^{[5]}$ study, they had higher age group (starting from 45 years old) and we acquired participants aged 40 years and older. Moreover, they had a higher cutoff value for TT $(<300 \mathrm{ng} / \mathrm{dl})$, but in our study, we used lower cutoff value of $<230 \mathrm{ng} / \mathrm{dl}$.

Another study was done by $\mathrm{Wu}$ et $a l^{[8]}, 2010$, that showed the prevalence of hypogonadism among 3369 male participants aged greater than 40 years was $17.0 \%$, with total testosterone level cutoff value of less than 11 $\mathrm{nmol} / \mathrm{l}(317 \mathrm{ng} / \mathrm{dl})$ and was $4.1 \%$ with total testosterone level cutoff value less than $8 \mathrm{nmol} / \mathrm{l}(231 \mathrm{ng} / \mathrm{dl})$, which is lower than our results. However, this can be explained by the type of participants, as in $\mathrm{Wu}$ et $a l .{ }^{[8]}$, the study participants were recruited from the general population, but in our study, the participants are patients attending the outpatient clinics in our tertiary hospital.

This explanation raises the issue that the symptoms of androgen deficiency are vague, the patients may relate it to aging process not to their disease, or the symptoms may be reflected by another disease. It is difficult to be measured and differentiate it from hormone-independent aging. This condition may result in significant detriment to quality of life and adversely affect the function of multiple organ systems $^{[11,12]}$.

In the present study, there is a weak negative correlation between total and free testosterone levels with age. This result is in agreement with other studies ${ }^{[13-15]}$. However, other studies showed that there is no decline in testosterone level in the blood with advancement of age ${ }^{[16-19]}$. Interestingly, only two studies showed that there is an increase in serum testosterone levels with aging in men rather than a decline ${ }^{[20,21]}$.

Our study showed that up to $19.2 \%$ of our study group had low androgen level based on total testosterone, and this percentage increased to $36.2 \%$ when we added the low free testosterone participants. This also accompanied by the high percentage of patients showing abnormal AMS score, denoting the presence of $93.2 \%$ of the patients having mild or moderate impairment. This should increase the awareness of late-onset hypogonadism among physicians dealing with middle and old age males, and the importance of total testosterone and free testosterone screening in such group of patients, especially in the presence of vague symptoms suggestive of hypogonadism.

\section{CONCLUSION}

The prevalence of hypogonadism among middle and old age males seeking medical consultation in different specialty may be high. Therefore, awareness of lateonset hypogonadism among physicians dealing with such patients should be raised.

\section{CONFLICT OF INTEREST}

There are no conflict of interests.

\section{REFERENCES}

1. Aras H, Bhasin S, Cunningha GR, Hayes FJ, Matsumoto AM, Synder PJ, Swerdloff RS, et al. Testosterone therapy in adult men with androgen deficiency syndromes: an endocrine society clinical practice guideline. J Clin Endocrinol Metab 2006; 91:1995-2010.

2. Nieschlag E, Swerdloff R, Behre HM, Gooren LJ, Kaufman JM, Legros JJ, et al. Investigation, treatment and monitoring of late-onset hypogonadism in males: ISA, ISSAM, and EAU recommendations. Int J Androl 2005; 28:125-127.

3. Heinemann L, Zimmermann T, Vermeulen A, Thiel C. A new 'Aging Male's Symptoms' (AMS) Rating Scale. The Aging Male 1999; 2:105-114.

4. Wang C, Nieschlag E, Swerdloff R, Behre HM, Hellstrom WJ, Gooren LJ, et al. Investigation, treatment, and monitoring of late-onset hypogonadism in males: ISA, ISSAM, EAU, EAA, and ASA recommendations. J Androl 2009; 30:1-9.

5. Mulligan T, Frick MF, Zuraw QC, Stemhagen A, McWhirter C. Prevalence of hypogonadism in males 
aged at least 45 years: the HIM study. Int J Clin Pract 2006; 60:762-769.

6. Araujo AB, O'Donnell AB, Brambilla DJ, Simpson WB, Longcope C, Matsumoto AM, et al. Prevalence and incidence of androgen deficiency in middle-aged and older men: estimates from the Massachusetts Male Aging Study. J Clin Endocrinol Metab 2004; 89:5920-5926.

7. Araujo AB, Esche GR, Kupelian V, O'Donnell $\mathrm{AB}$, Travison TG, William RE, et al. Prevalence of symptomatic androgen deficiency in men. J Clin Endocrinol Metab 2007; 92:4241-4247.

8. Wu FC, Tajar A, Beynon JM, Pye SR, Silman AJ, Finn $\mathrm{JD}$, et al. Identification of late-onset hypogonadism in middle-aged and elderly men. N Engl J Med 2010; 363:123-135.

9. Sun K, Liang GQ, Chen XF, Ping P, Yaw WL, Zhang $\mathrm{SJ}$, et al. Survey for late-onset hypogonadism among old and middle-aged males in Shanghai communities. Asian J Androl 2012; 14:338-340.

10. Liu CC, Wu WJ, Lee YC, Wang CJ, Ke HL, Li $\mathrm{WM}$, et al. The prevalence of and risk factors for androgen deficiency in aging Taiwanese men. J Sex Med 2009; 6:936-946.

11. Rhoden EL, Morgentaler A. Risks of testosteronereplacement therapy and recommendations for monitoring. N Engl J Med 2004; 350:482-492.

12. Morales A, Schulman CC, Tostain J, FCWW. Testosterone Deficiency Syndrome (TDS) needs to be named appropriately-the importance of accurate terminology. Eur Urol 2006; 50:407-409.

13. Mohr BA, Guay AT, O’Donnell AB, McKinlay JB. Normal, bound and nonbound testosterone levels in normally ageing men: results from the Massachusetts Male Ageing Study. Clin Endocrinol (Oxf) $2005 ; 62: 64-73$.
14. Svartberg J, Midtby M, Bonaa KH, Sundsfjord J, Joakimsen RM, Jorde R. The associations of age, lifestyle factors and chronic disease with testosterone in men: the Tromso Study. Eur J Endocrinol 2003; 149:145-152.

15. Harman SM, Metter EJ, Tobin JD, Pearson J, Blackman MR, Baltimore Longitudinal Study of A. Longitudinal effects of aging on serum total and free testosterone levels in healthy men. Baltimore Longitudinal Study of Aging. J Clin Endocrinol Metab 2001; 86:724-731.

16. Ramezani Tehrani F, Mansournia MA, SolaymaniDodaran M, Minooee S, Azizi F. Serum variations of anti-mullerian hormone and total testosterone with aging in healthy adult Iranian men: A populationbased study. PLoS One 2017; 12:e0179634.

17. Yeap BB, Almeida OP, Hyde Z, Norman PE, Chubb SA, Jamrozik K, Flick, et al. In men older than 70 years, total testosterone remains stable while free testosterone declines with age. The Health in Men Study. Eur J Endocrinol 2007; 156:585-594.

18. Frost M, Wraae K, Nielsen TL, Hougaard DM, Brixen K, Hagan C, Anders. A validated age-related normative model for male total testosterone shows increasing variance but no decline after age 40 years. PLoS One 2014; 9:e109346.

19. Frost M, Wraae K, Nielsen TL, et al. Similar reference intervals for total testosterone in healthy young and elderly men: results from the Odense Androgen Study. Clin Endocrinol (Oxf) 2013; 78:743-751.

20. Halmenschlager G, Rhoden EL, Riedner CE. The influence of age on bioavailable and free testosterone is independent of body mass index and glucose levels. World J Urol 2011; 29:541-546.

21. Rhoden EL, Teloken C, Sogari PR, Souto CA. The relationship of serum testosterone to erectile function in normal aging men. J Urol 2002; 167:1745-1748. 